\title{
Water Flow in the High Plains Aquifer in Northwestern OKahoma
}

\section{By Richard R. Luckey' ${ }^{1}$, Noel I. Osborn' ${ }^{2}$, Mark F. Becker ${ }^{1}$ and William J. Andrews ${ }^{1}$}

\section{Study Area}

The High Plains is a major agricultural area, supported primarily by water from the High Plains aquifer, which is used to irrigate wheat and corn and to raise cattle and swine.

The U.S. Geological Survey (USGS) and the Oklahoma Water Resources Board (OWRB) began a study of the High Plains aquifer in 1996. One purpose of the study was to develop a ground-water flow model that the OWRB could use to allocate the amount of water withdrawn from the aquifer.

The study area in Oklahoma covers all or parts of Beaver, Cimarron, Dewey, Ellis, Harper, Texas, and Woodward Counties. To provide appropriate hydrologic boundaries for the ground-water flow model, the study

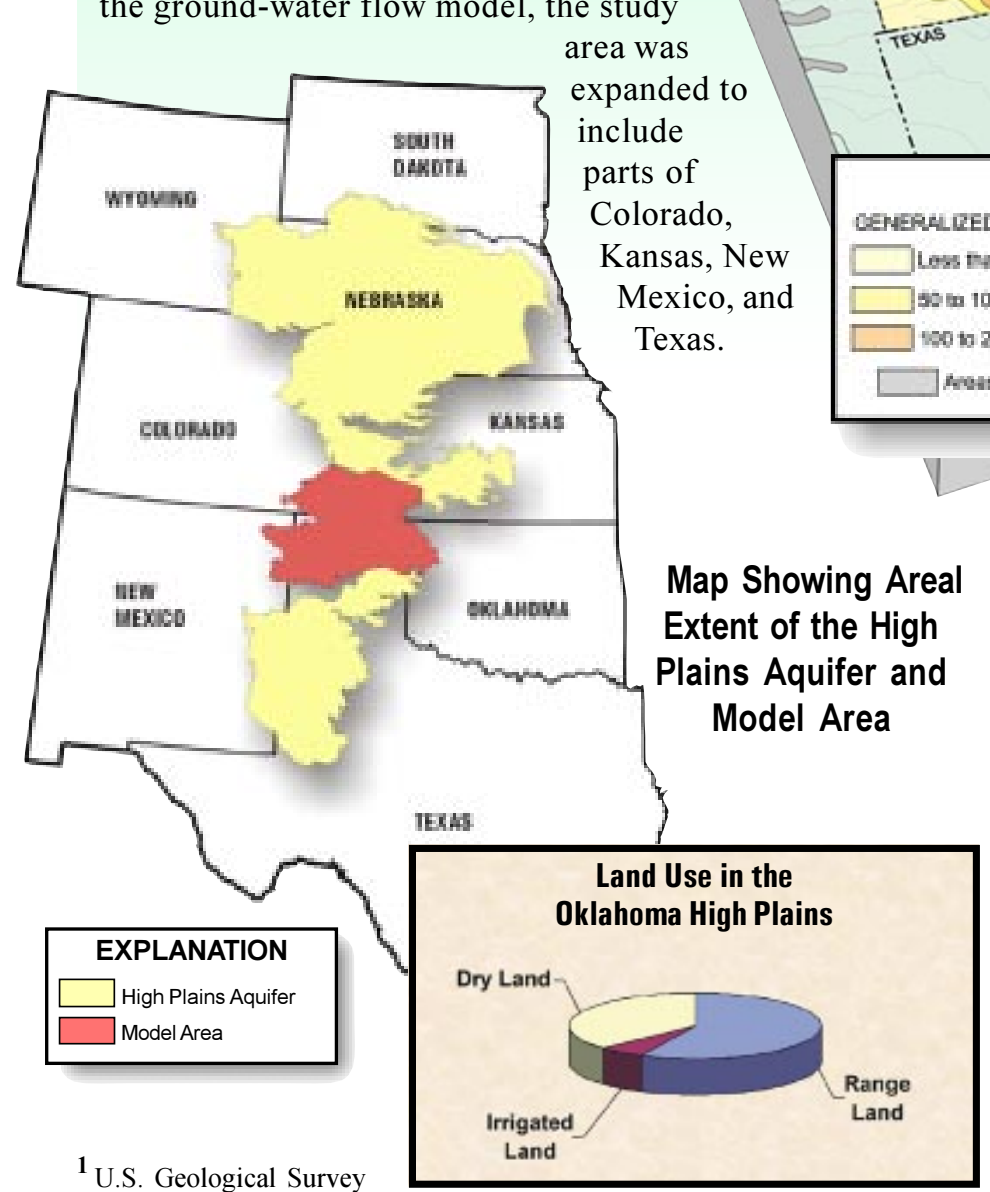

2 Oklahoma Water Resources Board

\section{Water Resources}

The High Plains aquifer underlies about 174,000 square miles in parts of eight states, including about 7,100 square miles in northwestern Oklahoma. Within Oklahoma, this aquifer consists of the saturated part of the Ogallala Formation and saturated

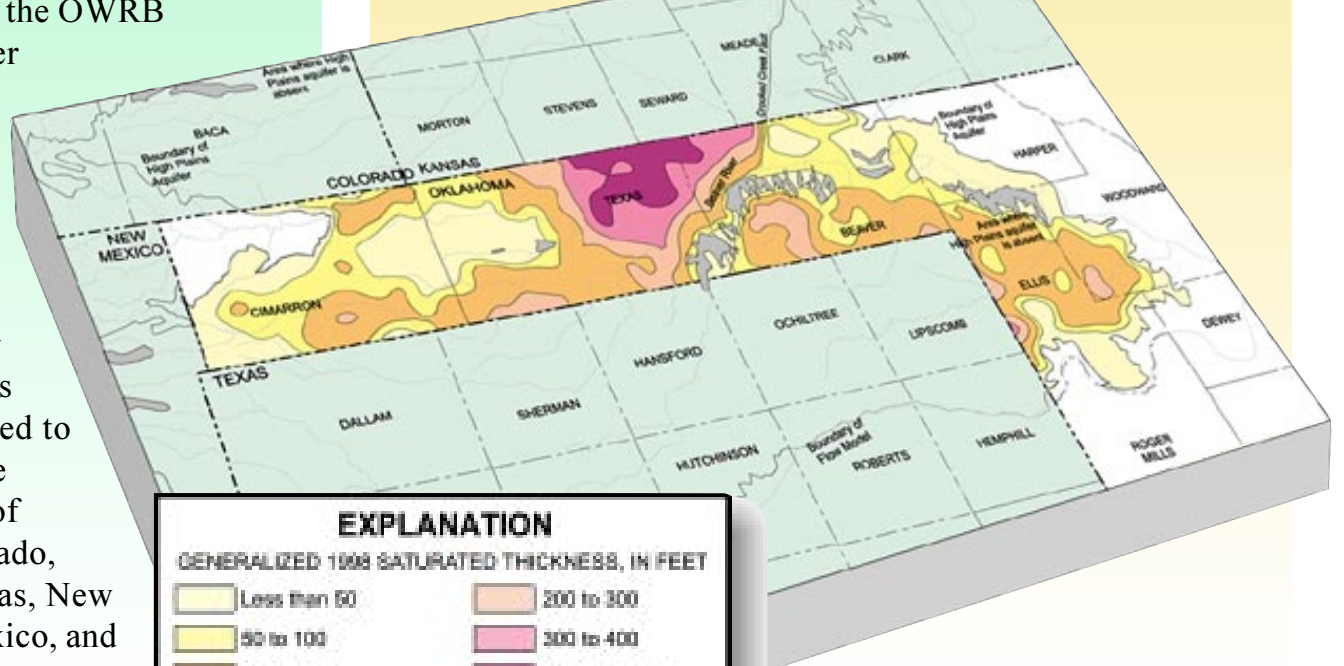

\section{Map Showing 1998 Saturated Thickness of High Plains Aquifer in Oklahoma}

material of Quaternary Age in hydraulic connection with the Ogallala Formation. The High Plains aquifer is commonly referred to as the Ogallala aquifer.

The High Plains aquifer is similar to a rigid sponge, partially saturated with water. The aquifer is composed of clay, silt, sand, and gravel; with the sand and gravel layers contributing most of the water to wells. Depth to water in the High Plains of Oklahoma ranges from less than 10 feet to more than 300 feet below the land surface. In 1998, the saturated thickness (the vertical thickness of an aquifer that is filled with water) ranged from nearly zero to almost 430 feet, with the greatest saturated thicknesses occurring in eastern Texas County and northwestern Beaver County.

Precipitation is the primary source of recharge to the aquifer. Other sources include seepage from streams and irrigation return flows. Ground water discharges from the aquifer to springs and streams, to adjoining formations and to the atmosphere by evapotranspiration where the water table is shallow. Water is artificially discharged from the aquifer by wells. 


\section{Water Use}

Most of the water pumped from the Oklahoma High Plains is used to irrigate crops. The remainder is used for livestock, municipal, and domestic needs. More than half of the water withdrawals from the aquifer occurs in Texas County. Livestock use increased from about 2 percent in 1992 to 5 percent in 1997 , due to a large increase in the number of swine (from 20,000 to $1,400,000)$.

Use of ground water for crop irrigation expanded rapidly after 1946, due largely to the development of center pivots, leading to declines in ground-water levels and stream flows over much of the Oklahoma High Plains. By 1998, water levels had declined more than 100 feet in small areas of Texas County and more than 50 feet in areas of Cimarron County.

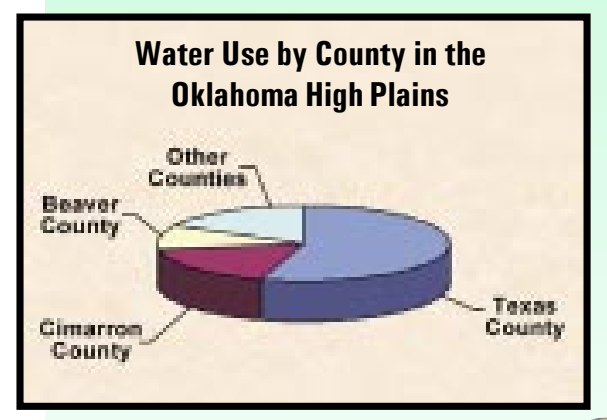

Only a small area of Beaver County had declines of more than 10 feet. In Ellis County, ground-water levels rose more than 10 feet during the period.
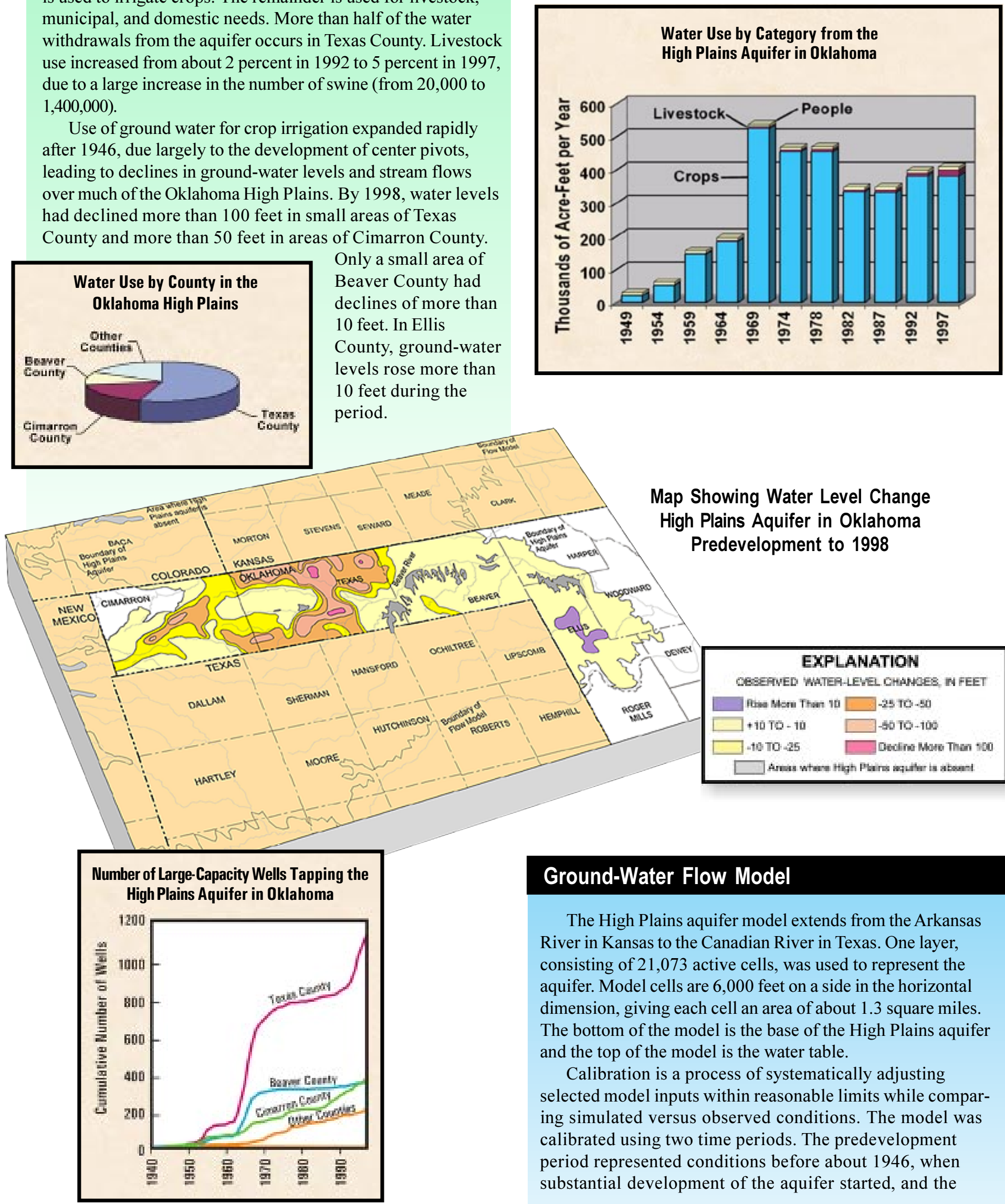

\section{Ground-Water Flow Model}

The High Plains aquifer model extends from the Arkansas River in Kansas to the Canadian River in Texas. One layer, consisting of 21,073 active cells, was used to represent the aquifer. Model cells are 6,000 feet on a side in the horizontal dimension, giving each cell an area of about 1.3 square miles. The bottom of the model is the base of the High Plains aquifer and the top of the model is the water table.

Calibration is a process of systematically adjusting selected model inputs within reasonable limits while comparing simulated versus observed conditions. The model was calibrated using two time periods. The predevelopment period represented conditions before about 1946, when substantial development of the aquifer started, and the 
development period from 1946 to the beginning of 1998.

In the predevelopment period, recharge from precipitation and hydraulic conductivity (the ability of the aquifer to transmit water) were varied to achieve the best fit between observed and simulated water levels and stream discharges. In the development period, specific yield (the ability of the aquifer to store and release water), recharge from irrigation return flows, and recharge from dryland cultivation were varied to achieve the best fit between observed and simulated changes in water levels and stream discharges.

\section{RESULTS}

Hydraulic conductivities and specific yields of the aquifer were determined by the calibrated model to be much less than originally estimated. In Oklahoma, hydraulic conductivities ranged from 10 to 122 feet per day, averaging 33 feet per day. Specific yields ranged from 4 percent to 27 percent, averaging 16 percent.

For the Oklahoma portion of the study area, recharge from precipitation ranged from 0.06 inch per year to 0.90 inch per year, averaging 0.18 inch per year. Recharge was greater (4.0 percent of precipitation) in areas having sand dunes or very sandy soil than in the remainder of the area $(0.37$ percent of precipitation).

Recharge from precipitation also was enhanced in areas cultivated for dry-land crops.

About 25 observation wells in the Oklahoma High Plains had rising water levels, which were attributed to enhanced recharge caused by dry-land cultivation.

Recharge to the aquifer due to irrigation return flow decreased from 24 percent of pumpage during the 1940 s and 1950 s, to 2 percent for the 1990s. This decrease was due to higher fuel costs and more efficient irrigation practices with center pivots, low-pressure pivots, and LEPA (low energy, precision application) systems.

Ground water is pumped out of the aquifer at a greater rate than it is replenished by recharge. In the Oklahoma portion of the study area, 389 thousand acre-feet of water were pumped in 1996-97, whereas only 175 thousand acre-feet were replenished by recharge.

\section{Typical Model Cell}

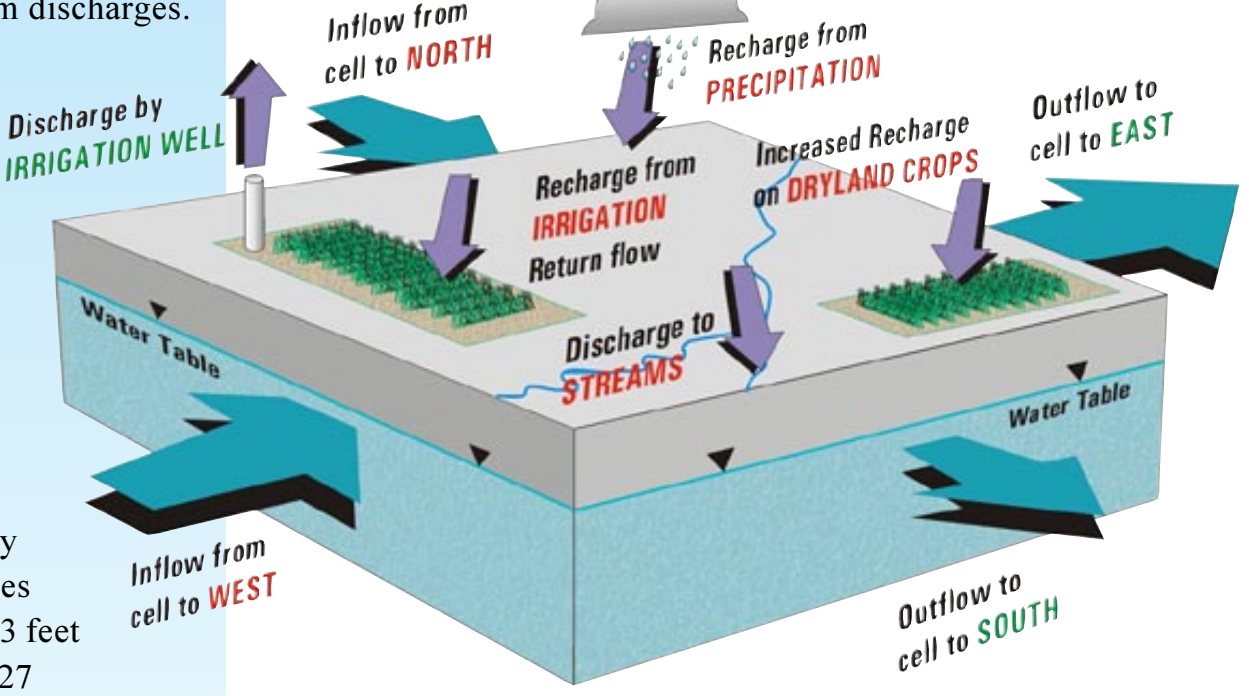

\section{WHAT IS A MODEL?}

A ground-water flow model is a generalized simulation of water flow in an aquifer, which can be used to estimate water levels, ground-water flow directions, and stream discharges, both spatially and over time. A model is based on equations that describe flow through porous media, such as sand and gravel, which accounts for the conservation of mass and energy in the system. A model is subdivided into cells, accounting for flows between the cells.

\section{Map Showing Mean Precipitation and Recharge Areas in Model Area}




\section{Projected Water Level Changes}

The model also was used to project water-level changes from 1998 to 2020. If water users continue to pump at 199697 rates, by 2020 ground-water levels will decline an additional 25-50 feet in parts of Texas County and by 10 to 25 feet in parts of Beaver, Ellis, and Cimarron Counties. In the remaining areas, ground-water levels were projected to rise or decline no more than 10 feet. Water-level declines were projected to be greatest in areas where irrigation development is greatest, and were projected to be less in areas where the saturated thickness is small. It is impossible to predict future pumpage, which is a complex function of pumping costs, crop prices, advances in technology, and many other variables.

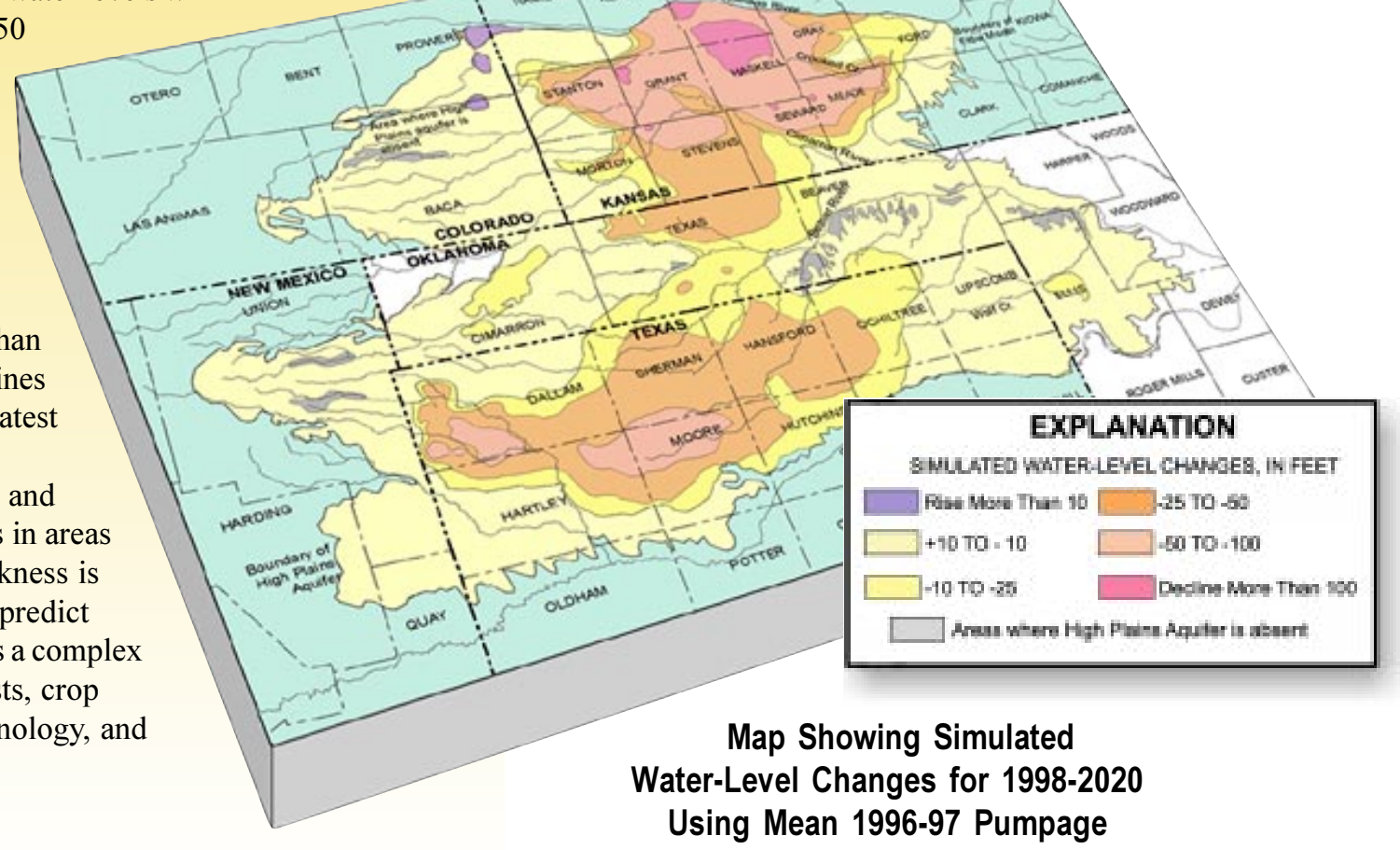

\section{Selected References}

Luckey, R.R., and Becker, M.F., 1998, Estimated predevelopment discharge to streams from the High Plains aquifer in northwestern Oklahoma, southwestern Kansas, and northwestern Texas: U.S. Geological Survey Water-Resources Investigations Report 97$4287,28 \mathrm{p}$.

McGuire, V.L., and Fischer, B.C., 1999, Water-level changes, 1980 to 1997, and saturated thickness, 1996-97, in the High Plains aquifer: U.S. Geological Survey Fact Sheet 124-99, 4 p.

Wahl, K.L., and Tortorelli, R.L., 1997, Changes in flow in the Beaver-North Canadian River basin upstream from Canton Lake, western Oklahoma: U.S. Geological Survey Water-Resources Investigation Report 96-4304, 58 p.

\section{For More Information}

Contact: U.S. Geological Survey

\section{District Chief}

202 NW $66^{\text {th }}$ Street, Building 7

Oklahoma City, OK 73116

(405) 810-4400

Additional earth science information can be found at the USGS home page at http://www.usgs.gov/ and the Oklahoma Water Resources Board home page at http://www.state.ok.us/ owrb/

Graphic design and layout, James Leewright, Oklahoma Water Resources Board

This fact sheet summarizes information contained in U.S. Geological Survey Water-Resources Investigations Report 99-4104, "Hydrogeology, water use, and simulation of flow in the High Plains aquifer in northwestern Oklahoma, southeastern Colorado, southwestern Kansas northwestern New Mexico, and northwestern Texas" by Richard R. Luckey and Mark F. Becker. Copies of that report can be purchased from U.S. Geological Survey, Branch of Information Services, Box 25286, Denver, CO, 80225-0286. 